\title{
Effect of Temperature on the Adsorption of Metallic Soaps of Castor Seed Oil onto Haematite
}

\author{
J.E Asuquo ${ }^{1}$, Udegbunam, I.S ${ }^{2}$, E.E Etim ${ }^{2 *}$ \\ ${ }^{I}$ Department of Chemistry, University of Uyo, Nigeria \\ ${ }^{2}$ Department of Chemical Sciences, Federal University, Wukari, Taraba, Nigeria
}

*Corresponding Author: E.E Etim, Department of Chemical Sciences, Federal University, Wukari, Taraba, Nigeria

\begin{abstract}
This study is based on the effect of temperature on the adsorption of three metallic soaps of castor seed oil onto haematite surface in aqueous medium. The results showed a decrease in adsorption density with increase in temperature to a minimum at $50^{\circ} \mathrm{C}$ for the various soaps. This can be due to the weakening of attractive forces between adsorbate and the adsorbent. This enhances the tendency of the adsorbate ions to escape from each adsorbent surface to the solution phase, hence desorption may start to occur above this temperature. However, between $60{ }^{\circ} \mathrm{C}$ and $70{ }^{\circ} \mathrm{C}$ adsorption equilibrium was attained. The maximum adsorption capacity for the adsorbates.
\end{abstract}

Keywords: haematite, Castor seed, temperature, adsorbent, adsorbate.

\section{INTRODUCTION}

Adsorption science has exhibited great potential in many technological and industrial systems such as filtration of impurities from liquid or gases, the bonding of molecules to the solid surface of a heterogenous catalyst, the segregation of surfactant molecules onto the surface of a liquid, and the migration of ions to the surface of a charged electrode. Temperature is a crucial parameter in adsorption reactions. According to the adsorption theory, adsorption decreases with an increase in temperature, and molecules adsorbed earlier on a surface tend to desorb from the surface at elevated temperatures. But for activated carbon, a different trend is noticed where decreasing viscosity and increasing molecular motion at high temperature allows the uptake of molecules into the pores more easily, causing adsorption to increase as temperature increases. However temperature has not been studied as relevant variable in bisorption experiments. The tests are usually performed at approximately $25-30^{\circ} \mathrm{C}$. However, a slight increases in cation uptake by seaweed in the range of 4 to $55^{\circ} \mathrm{C}$ has been reported (Horsfall and Spiff, 2005.)

Metallic soaps are metallic salts of fatty acids. They are groups of water-insoluble compounds containing alkaline earth or heavy metals combined with monobasic carboxylic acids of 7-22 carbon atoms (Lewkowitsch, 1969). They can be represented by the general formular (RCOO)xM where R is an aliphatic or alicyclic radical and $\mathrm{M}$ is a metal of valence $\mathrm{X}$. They differ from toilet soaps in their composition and insolubility in water. Their solubility or solvation in a variety of organic solvents accounts for their various uses. Soap molecules bear hydrophobic or hydrophilic parts which can be adsorbed selectively on the surface of the desired mineral particles to reduce wetting by water. Thereby enhance their floatation. The balance of dynamic forces between the concentration of adsorbate in bulk solution with that the interface for a particular systems leads to adsorption equilibrium. Adsorption and its phenomena have received a lot of attention by several investigators who reported the dependence of the process on factors such as temperature, pressure, effective surface area. $\mathrm{Ph}$, concentration, ionic charge, ionic strength, nature of adsorbate and adsorbent, (Ahalya et al., 2005, Ahalya et al., 2007, Ai et al., 2006, Arivoli et al., 2008, Babarinde et al., 2006, Bos et al.,1994, Chiou et al., 2003, Cordero et al.,2004, Gardea-Torresdey et al., 1998, Hadjar, et al., 2004, Horsfall et al., 2006, Kim et al., 2005, Krishnan and Anirudhan, 2003, Norde and Anusiem, 1992, Ofor, 1995, Ofomaja et al., 2005, Ogali et al., 2008, Quek et al., 1998, Raghuvanshi et al., 2004, Santamarina et al., 2002, Uzun and Guzel, 2004). 
Castor oils derived from castor plant (Ricinus communis L.), represents a potential by-product and it is used in many technical, medical and different industrial application like biodiesel productions (Amara and Salem, 2009). Castor oil has over 1000 industrial uses and because of this, its demand increases. A scientific investigation of the crop to improve its oil content will go a long way to meet up with the demand (Sepidar et al., 2009).

\section{MATERials AND MethodS}

Ore containing samples of haematite obtained from Itakpe, Nigeria (76.9\% iron) were crushed in the laboratory using jaw and roll crushers. Gravimetric method of jigging and tabling was employed in removing siliceous materials, while magnetic separation was used in separating magnetic materials from the ore sample. Sieve analyses were performed using the british standards sieve plates to obtain sample of haematite-70 micron. Mineralogical analysis of the ore sample was performed with volumetric and atomic absorption spectrometric (Buck Scientific atomic absorption spectopotometer model 205A) methods. Solutions of the reagents were prepared with distilled deionised water and sodium hydroxide and hydrochloric acid solutions were used for $\mathrm{pH}$ adjustments. BDh chemical reagents analar grade (of not less than $98 \%$ purity) were used in this study. Determination of specific surface area (SSA) was done by the ethylene-glycol-monoethyl ether (EGME) method (Cerator and Lutenegger, 2002)

\subsection{Soap Preparation}

The $50 \mathrm{~g}$ castor seed oil was added to each $50 \mathrm{ml}$ of $30 \%$ potassium hydroxide, calcium hydroxide and aluminium hydroxide, and $30 \mathrm{ml}$ of ethanol was added into each of the $600 \mathrm{ml}$ beakers, then heated at $90^{\circ} \mathrm{C}$ for $1 \mathrm{~h}$ in water bath with vigorous stirring until creamy-pasty soaps are formed. The $50 \mathrm{ml}$ of hot saturated sodium chloride solution was then added to each of the pasty soaps with vigorous stirring for short period and allowed to cool overnight. The soaps cake formed on the surface of the 'lye' were removed and air dired and stored in plastic containers (Tooley, 1976)

\subsection{Calibration Studies}

The electrical conductance of $25 \mathrm{~cm} 2$ soap (potassium, calcium and aluminium soaps of castor seed oil) solutions of different concentrations were measured at $290 \mathrm{C}$ and $\mathrm{pH} 7.31$, using an Electronic conductivity meter (model-90 check-mate deluxe field system-corning). From the result, a calibration graph of the soap conductance was plotted against the square root of soap concentrations based on the Kohlrausch law equation (Atkins, 1998);

$\Lambda_{m}=\Lambda_{m}^{o}-K C^{\frac{1}{2}}$

Where $\Lambda_{m}$ is the molar conductivity, $\Lambda^{o}{ }_{m}$ is the limiting molar conductivity, $\mathrm{C}$ is the concentration of the solution and $\mathrm{K}$ is a constant.

\section{RESULTS AND DISCUSSION}

Calculations from experimental results and sample analysis show that specific surface area (SSA) of haematite is $118.5 \mathrm{~m}^{2} / \mathrm{g}$. this value is in agreement with that obtained by Ibezim-Ezeani and Anusiem (2009), for haematite using the same method.

Table1. Chemical Composition of haematite $\left(\mathrm{Fe}_{2} \mathrm{O}_{3}\right)$

\begin{tabular}{|l|l|}
\hline Chemical Composition & Haematite (\%) \\
\hline $\mathrm{Fe}^{3+}$ & 76.9 \\
\hline $\mathrm{S}^{2-}$ & 0.1 \\
\hline $\mathrm{Al}^{3+}$ & 4.1 \\
\hline $\mathrm{Si}^{4+}$ & 8.3 \\
\hline $\mathrm{Mg}^{2+}$ & 0.4 \\
\hline $\mathrm{Ca}^{2+}$ & 0.3 \\
\hline $\mathrm{P}^{3-}$ & 0.1 \\
\hline $\mathrm{Ti}^{4+}$ & 0.2 \\
\hline $\mathrm{Mn}^{2+}$ & 0.1 \\
\hline
\end{tabular}


Table2. $K^{+}$Castor seed oil soap adsorption density at different temperatures for haematite

\begin{tabular}{|l|l|l|l|l|l|}
\hline $\begin{array}{l}\text { Temperature } \\
\left({ }^{\circ} \mathrm{C}\right)\end{array}$ & $\begin{array}{l}\text { Initial } \mathrm{K}^{+} \\
\text {Castor oil } \\
\text { Soap g/litre }\end{array}$ & $\begin{array}{l}\text { Equilibrium } \\
\text { conductance } \\
(\mu \mathrm{S} / \mathrm{cm})\end{array}$ & $\begin{array}{l}\text { Equilibrium }\left(\mathrm{K}^{+}\right) \\
\text {Castor soap } \\
\text { concentration }(\mathrm{g} / \mathrm{l})\end{array}$ & $\begin{array}{l}\mathrm{K}^{+} \text {Castor adsorbed per } \\
\text { gram of haematite }(\mathrm{g})\end{array}$ & $\begin{array}{l}\text { Adsorption } \\
\text { density of } \mathrm{K}^{+} \\
\text {castor oil soap } \\
\text { per } \mathrm{m}^{2} \\
\text { Haematite } \\
\text { surface g/g }\end{array}$ \\
\hline 29 & 1.0 & 58 & 2.07 & 7.93 & 0.00669 \\
\hline 40 & 1.0 & 91 & 5.31 & 4.69 & 0.00395 \\
\hline 50 & 1.0 & 97 & 6.37 & 3.63 & 0.00306 \\
\hline 60 & 1.0 & 103 & 7.23 & 2.77 & 0.00233 \\
\hline 70 & 1.0 & 104 & 7.46 & 2.54 & 0.00214 \\
\hline
\end{tabular}

Table3. $\mathrm{Ca}^{2+}$ Castor seed oil soap adsorption density at different temperature for haematite

\begin{tabular}{|c|c|c|c|c|c|}
\hline $\begin{array}{l}\text { Temperature } \\
\left({ }^{\circ} \mathrm{C}\right)\end{array}$ & $\begin{array}{l}\text { Initial } \mathrm{Ca}^{2+} \\
\text { Castor oil } \\
\mathrm{g} / \text { litre }\end{array}$ & $\begin{array}{l}\text { Equilibrium } \\
\text { conductance }(\mu \\
\text { S/cm) }\end{array}$ & $\begin{array}{l}\text { Equilibrium }\left(\mathrm{Ca}^{2+}\right) \\
\text { Castor soap } \\
\text { concentration }(\mathrm{g} / \mathrm{l}\end{array}$ & $\begin{array}{l}\mathrm{Ca}^{2+} \text { Castor } \\
\text { adsorbed per } \\
\text { gram of } \\
\text { haematite }(\mathrm{g})\end{array}$ & $\begin{array}{l}\text { Adsorption } \\
\text { density of } \\
\mathrm{Ca}^{2+} \text { castor oil } \\
\text { soap per } \mathrm{m}^{2} \\
\text { Haematite } \\
\text { surface } \mathrm{g} / \mathrm{g}\end{array}$ \\
\hline 29 & 1.0 & 63 & 2.53 & 7.47 & 0.00630 \\
\hline 40 & 1.0 & 93 & 5.62 & 4.38 & 0.00369 \\
\hline 50 & 1.0 & 100 & 6.67 & 3.33 & 0.00281 \\
\hline 60 & 1.0 & 104 & 7.44 & 2.56 & 0.00216 \\
\hline 70 & 1.0 & 105 & 7.66 & 2.34 & 0.00197 \\
\hline
\end{tabular}

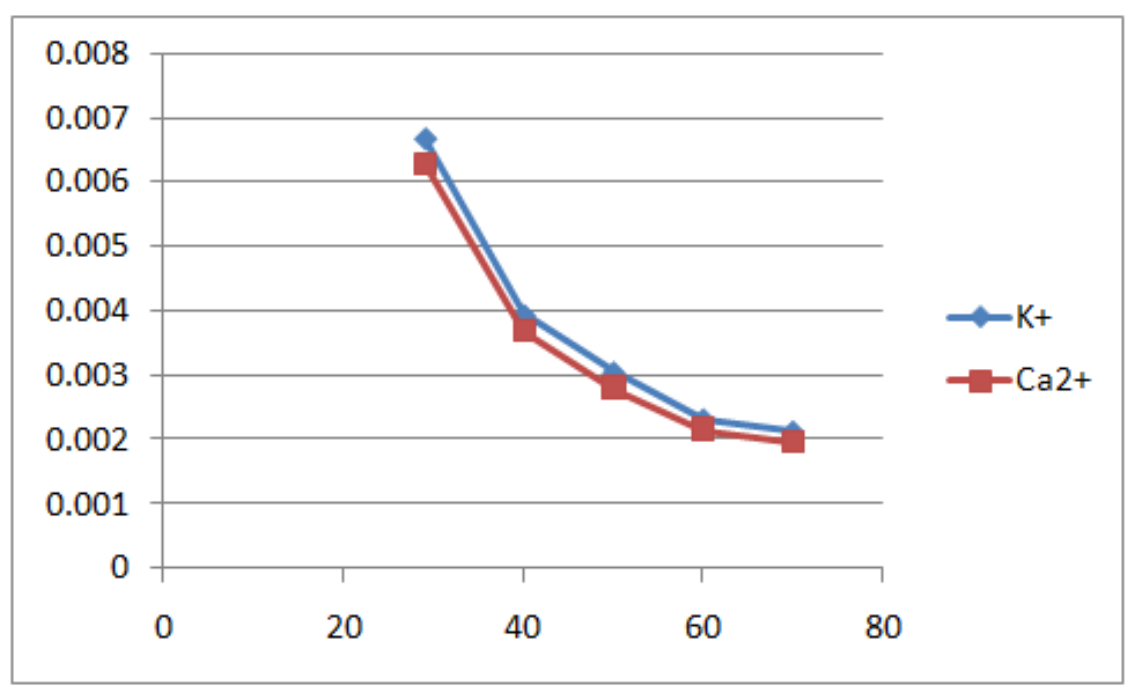

Fig1. Plot of adsorption density at different temperatures for $\mathrm{K}^{+}$and $\mathrm{Ca}^{2+}$ of Castor seed oil soaps

Tables 2 and 3 show the adsorption densities of $\mathrm{K}^{+}$, and $\mathrm{Ca}^{2+}$ soaps of castor seed oil onto adsorbent (haematite) at various temperatures. Fig 1 shows the plot of these adsorption densities as a function of temperature. Fig 1 and tables 2 and 3 show that the adsorption densities decrease with increasing temperature to minimum at $50^{\circ} \mathrm{C}$ for the various soaps. The decrease in adsorption density with increasing temperature is likely due to the weakening of attractive forces betweenthe adsorbate and the adsorbent. This enhances the tendency of the adsorbate ions to escape from each adsorbent surface to the solution phase, hence adsorption may start to occur above this temperature.

However, between $60^{\circ} \mathrm{C}$ and $70^{\circ} \mathrm{C}$, the adsorption density remains constant. This may be attributable to the denaturation or distortion of the adsorbate molecules. This will cause the structured water molecules surrounding the hydrophobic (non- polar) groups to be disrupted (Anusiem, 1999). These are likely to alter the orientation and effective interaction at the site. Physical adsorption usually decrease with increase in temperature while chemisorption is favoured at higher temperature (Houwing and Salomon, 1965). For physical adsorption, we expect that the adsorption will be higher at the lower temperature than that at higher temperature where as if the process is a chemical 
absorption, the reverse is true. (Ebenso, 2003, 2004). The observed decreased temperature in adsorption density suggests that the adsorption on the adsorbent is largely a physical process.

This is in line with the results obtained by Horsfall and Spiff (2005a), Ekpe et al., (2001) and Fouda et al., (2000). However, generally, the adsorption theory suggest that adsorption decreases with increase in temperature and that molecules adsorbed earlier on a surface tends to desorb at elevated temperatures, Sharma and Sharma (2000).

Also at high temperature, the thickness of the boundary layer decreases, due to the increased tendency of the metal ion to escape from the ore surface to the solution phase which results in a decrease in adsorption as temperature increases. (Aksu and Kutsal, 1991).

Considering the various soaps of castor oil, potassium soap has the highest adsorption density followed by calcium soap. This indicates that there is a correlation between the adsorption density and the size to the charge ratio of the cations which are 0.75 and 2.02 for potassium and calcium respectively. Therefore, the smaller the size the charge ratio, the greater the adsorption density. The likely origin of these differences may be related to the increased diffusion rate of smaller ions to the surface of the adsorbent.

\section{CONClusion}

This study has shown the effect of adsorption of potassium, calcium of castor seed oil onto haematite. The results showed that the adsorption densities decrease with increasing temperature to a minimum at $50^{\circ} \mathrm{C}$ for the various soaps. The decrease in adsorption density with increasing temperature is likely due to the weakening attractive forces between adsorbate and adsorbent. Adsorption equilibrium was attained between $60^{\circ} \mathrm{Cand} 70^{\circ} \mathrm{C}$. The maximum adsorption capacity for the adsorbate is in the order: potassium soap > calcium soap of castor seed oil which is in the reverse of the size to charge ratio of the cations due to increased diffusion rate of smaller ion to the surface of the adsorbent. The level of adsorption of all the adsorbates on the surface of the adsorbent suggest that all metallic soaps of castor oil in the study show a reasonable degree of surface coverage that may warrant their use as collector reagents in floatation separation of haematite from its ore.

\section{REFERENCES}

Ai, J.Z., Guo, X.P., Qu, J. E., Chen, Z. Y., and Zheng, J.S. (2006). Adsorption behavior and synergistic mechanism of a cation inhibitor and KI on the galvanic electrode. Colloids Surface A, Physicochemical Engineering Aspects, 281:147-155

Aksu, Z., and Kutsal, T.A. (1991). A bioseparation process for removing $\mathrm{Pb}(\mathrm{II})$ ions from waste water by using C. vulgaris. Journal of Chemical Technology, Biotechnology, 55:108-118.

Alhaya, N., Kanamadi, R.D., and Ramachandra, T.V. (2005). Biosorption of chromium (VI) from aqueous solutions by the husk of Bengal gram (Cicer arientinium). Electronic Journal of Biotechnology, 8:331-325.

Alhaya, N., Kanamadi, R.D., and Ramachandra, T.V. (2007). Cr (VI) and Fe (III) removal using cajanus cajan husk. Journal of Environmental Biology, 28: 765-769

Anusiem, A.C.I. Principles of general Chemistry(1999): A Programmed Approach. Publication of pam Unique, Ozuoba, Nigeria, p. 251

Atkins, P.W. Physical Chemistry, $6^{\text {th }}$ Ed., Oxford University Press, New York, 1998, p775-777.

Babarinde, N.A.A., Babalola, J.O., and Sanni, R.A. (2006). Biosorption of lead ions from aqueous solution by maize leaf. International Journal of Physical Science, 1:23-26.

Bos, M.A., Shervani, Z., Anusiem, A. C.I., Giesbers, M., Norde, W., and Kleijn, J.M. (1994). Influence of the electrical potential of the interface on the adsorption of proteins. Colloids Surface B: Biointerfaces, 3:91100

Cerrato A.B., and Lutennegger, A.J., (2002). Determination of surface area of fine-grained soils by the ethylene glycol monoethyl ether (EGME) method. Geotechnology Testing Journal, 3:1-7

Chiou, M., Ho, P., and Hsing-Ya, L., (2003). Adsorption behavior of dye AAVN and RB4 in acid solutions on chemically cross-linked chitosan beads. Journal of China Institute of Engineering, 34:625-634

Cordero, B., Lodeiro P., Herrero, R., and Sastre de Vincente, M.E., (2004). Biosorption of cadmium by Fucus spiralis. Environmental Chemistry, 1:180-187.

Ebenso, E.E. (2004). Effects of methylred and halide ions on the corrosion aluminium in $\mathrm{H}_{2} \mathrm{SO}_{4}$. Bulletin of Electrochemistry, 20:551-559.

Ekpe, U.J., Okafor P.C., Ebenso E.E., Offiong, O.E., and Ita, I. B.. (2001). Mutual effects of thiosemicarbazone derivatives on the acidic corrosion of aluminium. Bulletin of Electrochemistry, 17:131-135 
Gardea-Torresdey, J.L., Tiemann, K.J., Dokken, K., and Gamez, G. (1998). Investigation of metal binding in alfafa biomass through chemical modification of amino and sulphydryl ligands. Proceedings of the 1998 Conference on Hazard Waste Research, p111-118.

Hadjar, H., Hamdi, B., and Kessaissia, Z. (2004). Adsorption of heavy metals ions on composite materials prepared by modification of natural silica. Desalination, 167:115-174.

Horsfall, M. Jnr., Abia, A.A. and Spiff, A.I. (2006). Kinetic studies on the adsorption of $\mathrm{Cd} 2+, \mathrm{Cu} 2+$, and $\mathrm{Zn} 2+$ ions from aqueous solutions by cassava (Manihot esculenta vanz) tuber bark waste. Bioresource Technology, 97:283-291.

Horsfall, M.Jnr., and Spiff, A.I. (2005). Equilibrium sorption study of Al3+, Co2+ and Ag2+ in aqueous solutions by fluted pumpkin (Telfaria occidentalis Hook F.) waste biomass. Acta. Chim. Slov., 52:174181.

Ibezim-Ezeani, M.U., and Anusiem, A.C.I. (2009). Studies on the adsorption of palmitate and laurate soaps onto some metal ore surfaces in queius media. Scentia Aficana, 8:31-34.

Kim, T.Y., Sun-Kuu, P., Sung-tony, C., Kim, H.B., Kang, Y., Kim, S.D. and Kim, S.J. (2005). Adsorption of heavy metals by brewery biomass. Korean Journal of Chemical Engineering, 22:91-98.

Krishnan, K.A., and Anirudha, T.S.(2003). Removal of cadmium(II) from aqueous solution by steam-activated sulphurised carbon prepared from sugar-cane baggase pith:Kinetics and equilibrium studies. Water SA, 29:147-156.

Lewkowwitsch, J.I., (1969). Chemical Technology and Analysis of Oils, fats and waxes. The Macmillan Company, New York, p134-136.

Norde, W. and Anusiem, A.C.I. (1992). Adsorption, desorption and re-adsorption of proteins on solid surfaces. Colloid Surfaces, 66:73-80.

Ofomaja, A.E., Unuabonah, E.I. and Abiola, O.N., (2008). Removal of lead from aqueous solution by palm kernel fibre. South Africa Journal of Chemistry, 58:127-130.

Ogali, R.E., Akaranta, O., and Aririguzo, V.O. (2008). Removal of some metal ions from aqueous solution using orange mesocarp. African Journal of Biotechnology, 7:3073-3076.

Quek, S.Y., Wase, D.A.J., and Foster, C.F. (1998). The use of sago waste for the sorption of head and copper. Water SA. 24:251-256.

Raghuvanshi, S.P., Singh, R., and Kaushik, C.P. (2004). Kinetic study of methylene blue dye bioadsorption on baggasse. Applied Ecological and Environmental Research, 2(2): 233-241.

Satamarina, J.C., Klein, K.A, Wang, Y.H. And Prencke, E. (2002). Specific surface:Determination and relevance. Canadian Geotecnology Journal, 39:233-241.

Sharma, K.K, and Sharma L.K. (2000). A TextBook of Physical Chemistry. $4^{\text {th }}$ Ed. Revised Edition, Vikas Publishing House Pvt Ltd, New Delhi.

Tooley, P., (1976). Experiments in Applied Chemistry. Published by John Murray, London, p.26

Uzun, I., and Guzel, F.(2004). External mass transfer studies during the adsorption of some dyestuff and pnitrophenol onto chitosan from aqueous solution. Turkish Journal Chemistry, 28:713-740.

Citation: J. Asuquo et al., "Effect of Temperature on the Adsorption of Metallic Soaps of Castor Seed oil onto Haematite", International Journal of Advanced Research in Chemical Science (IJARCS), vol. 4, no. 6, pp. 4044, 2017. http://dx.doi.org/10.20431/2349-0403.0406005

Copyright: (C) 2017 Authors. This is an open-access article distributed under the terms of the Creative Commons Attribution License, which permits unrestricted use, distribution, and reproduction in any medium, provided the original author and source are credited. 